Catatan Jenis Dipterocarpus Gaertn. f. (1788) di Resort Mentatai Seksi Pengelolaan Taman Nasional Wilayah 1 Nanga Pinoh Taman Nasional Bukit Baka Bukit Raya

\title{
Notes of Dipterocarpus Gaertn. $f$. (1788) Species at Mentatai Resort Nanga Pinoh Region 1 National Park Management Section Bukit Baka Bukit Raya National Park
}

\author{
Gunawan Wibisono ${ }^{1 *}$, Rafdinal ${ }^{1}$, Riza Linda ${ }^{1}$ \\ 1Program Studi Biologi, Fakultas Matematika dan Ilmu Pengetahuan Alam, \\ Universitas Tanjungpura, Jl. Prof Dr. Hadari Nawawi Bansir Laut, Kec. \\ Pontianak Tenggara, Pontianak, Indonesia
}

Received: 07 Mei 2021;

Accepted: 29 Juni 2021;

Published: 30 Juni 2021

KATA KUNCI Dipterocarpus, Dipterocarpaceae, TNBBBR

KEYWORDS

Resort Mentatai merupakan satu dari enam Resort Taman Nasional Bukit Baka ABSTRAK Bukit Raya yang menyusun Jantung Borneo (Heart of Borneo). Resort Mentatai Seksi Pengelolaan Taman Nasional Wilayah I Nanga Pinoh, Taman Nasional Bukit Baka Bukit Raya merupakan tempat pemantauan dan pelepas liaran orangutan. Ekosistem Dipterocarpaceae Taman Nasional Bukit Baka Bukit Raya Mengalami penurunan dari 46\% menjadi 33\% untuk periode 2009 hingga 2017. Penelitian ini dilakukan selama 3 bulan dari Oktober hingga Desember 2019 menggunakan Cruise method. Hasil penelitian diperoleh 3 jenis Dipterocarpus yaitu Dipterocarpus oblongifolius Bl., Dipterocarpus gracilis Bl., dan Dipterocarpus pachyphyllus Meijer.

ABSTRACT Resort Mentatai is one of the six resorts of Bukit Baka Bukit Raya National Park that make up the Heart of Borneo. The Management Section of Mentatai resort in Nanga Pinoh Region I Bukit Baka Bukit Raya National Park is a place for monitoring and releasing of orangutans. The Dipterocarpaceae ecosystem in Bukit Baka Bukit Raya National Park has decreased from 46\% to 33\% for the period 2009 to 2017. This research aims to find out the species of Dipterocarpus found in the Mentatai resort area. The research was conducted for 3 months from October to December 2019 using the cruise method. The results were obtained 3 Dipterocarpus Gaertn. f., species such as Dipterocarpus oblongifolius Bl., Dipterocarpus gracilis Bl., and Dipterocarpus pachyphyllus Meijer.

*Correspondence:

Email: gunawandrg@student.untan.ac.id

\section{Pendahuluan}

Kalimantan merupakan bagian dari pulau Borneo memiliki keragaman jenis tertinggi Dipterocarpaceae sebesar 59\% (267 jenis) (Ashton, 1982). Dipterocarpus Gaertn. 
f. (1788), merupakan kelompok yang menyusun hutan campuran Dipterocarpaceae Kalimantan dengan keanekaragaman jenis berjumlah 28 jenis $(47,6 \%)$ (Purwaningsih, 2004). Kalimantan termasuk pulau dari Indonesia yang mengalami degradasi populasi Dipterocarpaceae yang sangat cepat (Purwaningsih, 2004).

Wilayah administratif Taman Nasional Bukit Baka Bukit Raya (TNBBBR) terletak di jantung Borneo (Heart of Borneo). TNBBBR secara administratif merupakan bagian dari Kabupaten Katingan Provinsi Kalimantan Tengah dan Kabupaten Melawi serta Kabupaten Sintang Provinsi Kalimantan Barat. Resort Mentatai sebagai bagian dari seksi pengelolaan Taman Nasional Wilayah I TNBBBR terletak di Kabupaten Sintang dan Melawi Provinsi Kalimantan Barat. Resort mentatai merupakan satu dari enam Resort yang menyusun Heart of Boeneo. Resort Mentatai memiliki fungsi penting sebagai tempat rehabilitasi dan pelepasliaran orang utan. Effendy (2009) menyatakan, luas ekosistem hutan Dipterocarpaceae TNBBBR sebesar $46 \%$. Penebangan pohon kelompok perdagangan menjadi faktor degradasi dan penurunan ekosistem hutan dipterocarp TNBBBR menjadi 33\% (Raharjo, 2017). Potensi hasil hutan berupa kayu Dipterocarpaceae memiliki nilai ekonomi yang tergolong tinggi di pasar southeast Asia (Bawa in Appanah \& Turnbul, 1998).

Produk minor non kayu, resin, dammar dan kamper Dipterocarpaceae cendrung diabaikan karena nilai ekonomi yang lebih rendah (Purwaningsih, 2004). Identifikasi yang terbatas terhadap jenis yang dikenal dengan baik dapat menyebabkan eksploitasi pada jenis tertentu (Whitemore et al., 1999). Jenis-jenis Dipterocarpus spp., di Resort Mentatai belum pernah dilaporkan secara ilmiah dan spesifik. Penelitian ini bertujuan untuk mengetahui jenis-jenis Dipterocarpus spp., di Resort Mentatai Seksi Pengelolaan Taman Nasional Wilayah I Taman Nasional Bukit Baka Bukit Raya.

\section{Metode Penelitian}

\subsection{Waktu dan Tempat Penelitian}

Penelitian dilaksanakan selama 3 bulan dari Oktober 2019 hingga Desember 2019. Pengambilan sampel Dipterocarpaceae dilaksanakan di Resort Mentatai, Seksi Pengelolaan Taman Nasional Wilayah I Nanga Pinoh, Taman Nasional Bukit Baka Bukit Raya (TNBBBR). Identifikasi sampel dilaksanakan di Laboratorium Program Studi Biologi, Fakultas Matematika dan Ilmu Pengetahuan Alam, Universitas Tanjungpura, Pontianak.

\subsection{Alat dan Bahan}

Alat yang digunakan dalam penelitian ini adalah alat tulis, benang, sasak press herbarium, botol sprayer, gunting, GPS (Global Positioning System), kamera digital, 
plastik packing, corrugated board, label, koran, tali rafia, selotip dan galah pruning. Bahan yang digunakan dalam penelitian adalah alkohol $70 \%$.

\subsection{Deskripsi Umum Lokasi Penelitian}

Taman Nasional Bukit Baka Bukit Raya (TNBBBR) merupakan kawasan pelestarian alam yang terletak di Provinsi Kalimantan Barat dan Kalimantan Tengah. Letak geografis kawasan antara $112^{\circ} 12^{\prime} 12.345^{\prime \prime}-122^{\circ} 56^{\prime} 31.295^{\prime \prime}$ Bujur Timur dan 0²8'41.32-0’56'22.252 Lintang Selatan dengan total luas kawasan 181.090 Ha. Bagian selatan kawasan termasuk wilayah administratif Kabupaten Katingan Provinsi Kalimantan Tengah dan sebelah Utara merupakan wilayah Kabupaten Sintang dan Melawi Provinsi Kalimantan Barat (Effendy, 2009).

Resort Mentatai terletak di Kecamatan Menukung Kabupaten Melawi. Luas area keseluruhan Resort Mentatai 24.465 Ha (10,43\%) dan terbagi menjadi 4 zona yaitu zona inti, rimba, pemanfaatan dan pemafaatan tradisional. Resort Mentatai sebelah Barat berbatasan dengan Resort Belaban dan sebelah Timur berbatasan dengan Resort Rantau Malam. Resort Mentatai sebelah Timur dan Resort Rantau Malam sebelah barat merupakan perbatasan daerah administratif Kabupaten Melawi dan Sintang. Arah Selatan Resort Mentatai dan Utara Resort Kuluk Sepangi merupakan perbatasan antara Provinsi Kalimantan Barat dan Kalimantan Tengah (Raharjo, 2017).

\subsection{Metode Kerja}

\subsubsection{Pengambilan Sampel Tumbuhan Dipterocarpaceae}

Pengambilan sampel menggunakan metode jelajah (Cruise Method) menyusuri jalan setapak yang berada di Zona Rimba Resort Mentatai Taman Nasional Bukit Baka Bukit Raya (Rugayah et al., 2005). Lokasi sampling Dipterocarpaceae akan dimulai dari Camp sementara Cuhai dengan letak geografis 112 $23^{\prime} 15.9^{\prime \prime}$ Bujur Timur dan $00^{\circ} 35^{\prime} 32.7^{\prime \prime}$ Lintang Selatan. Penyusuran dilaksanakan terhadap 3 jalan setapak berbeda pada kisaran ketinggian 29-750 mdpl. Sampel Dipterocarpaceae yang ditemukan didokumentasi, diambil dan diberi etiket gantung yang berisi keterangan mengenai nomor koleksi, tanggal pengambilan sampel, nama kolektor, lokasi pengambilan sampel, nama ilmiah, nama daerah, habitat, dan deskripsi singkat meliputi bentuk daun, warna daun, bentuk batang dan tipe perbungaan untuk pembuatan herbarium.

\subsubsection{Pembuatan Herbarium}

Teknik pembuatan herbarium meliputi herbarium basah dan herbarium kering. Herbarium di buat setelah pengambilan sampel dari masing-masing titik ditemukannya sampel dan dilakukan segera sebelum tumbuhan mengalami perubahan bentuk. Sampel diambil meliputi organum nutritivum (ranting dan daun) 
dan organum reproductioum (bunga, buah dan biji). Tahap herbarium kering dimulai dengan pengambilan sampel dan dibersihkan dari kotoran yang menempel. Sampel yang telah bersih ditempatkan pada kertas koran (satu kertas koran untuk masingmasing sampel bolak balik), disusun pada lembaran-lembaran dengan pembatas kardus $2 \mathrm{~cm}$ dan diapit sedemikian rupa dengan bilah bambu serta diikat dengan sabuk membentuk sasak. Sampel disiram dengan alkohol 70\%. Sampel dikeringkan di bawah sinar matahari hingga kering (tidak terasa dingin ketika diusap) secara bertahap (Tjitrosoepomo, 1991).

Mounting terhadap sampel menggunakan bahan yang dapat menempelkan spesimen cukup erat pada kanvas (Tjitrosoepomo, 1991). Sampel yang telah kering dilakukan mounting dengan metode Spatula and Needle (S \& N) menggunakan lem Polifinil alkohol (PVA) terhadap lembaran kertas karton 28,5 x $41 \mathrm{~cm}$ dengan cara dijahit serta dipasang etiket (label) (Tucker \& Calabrese, 2005).

Herbarium basah meliputi beberapa bagian tumbuhan yang tidak memungkinkan dikemas dalam herbarium kering (kadar air yang tinggi). Bagian sampel dibersihkan dari kotoran dan disimpan dalam wadah berisi alkohol $70 \%$. Wadah sampel disesuaikan terhadap bagian yang ditemukan (Tjitrosoepomo, 1991).

\subsubsection{Identifikasi Tumbuhan Dipterocarpaceae}

Sampel diidentifikasi dengan melihat karakter morfologi luar yang meliputi bagian vegetatif akar, batang dan daun serta bagian generatif bunga, buah dan biji dari setiap sampel yang ditemukan. Identifikasi dilaksanakan dengan mencocokan karakteristik seluruh sampel terhadap sumber acuan identifikasi yang meliputi, buku Ashton (1982), Basey (1915), Chua et al. (2012), Dasuki (1991), APG IV (2016), Heywood et al. (1978), Kartasujana \& Suherdie (1993), Martawijaya et al. (2005) dan Singh (2009).

\subsubsection{Pembuatan Kunci Determinasi}

Kunci determinasi dibuat dengan mencocokan karakter morfologi setiap sampel terhadap kunci determinasi Dipterocarpaceae yang terdapat pada sumber identifikasi. Tipe kunci determinasi yang digunakan adalah bracket key. Pertanyaan ditujukan untuk setiap sampel yang diidentifikasi hingga ditemukan karaker yang cocok dan dibuat pernyataan berlawanan (Tjitrosoepomo, 1985). Kunci determinasi dibuat meliputi habitus, akar, batang, daun, bunga, buah dan biji (Newman et al., 1999). 


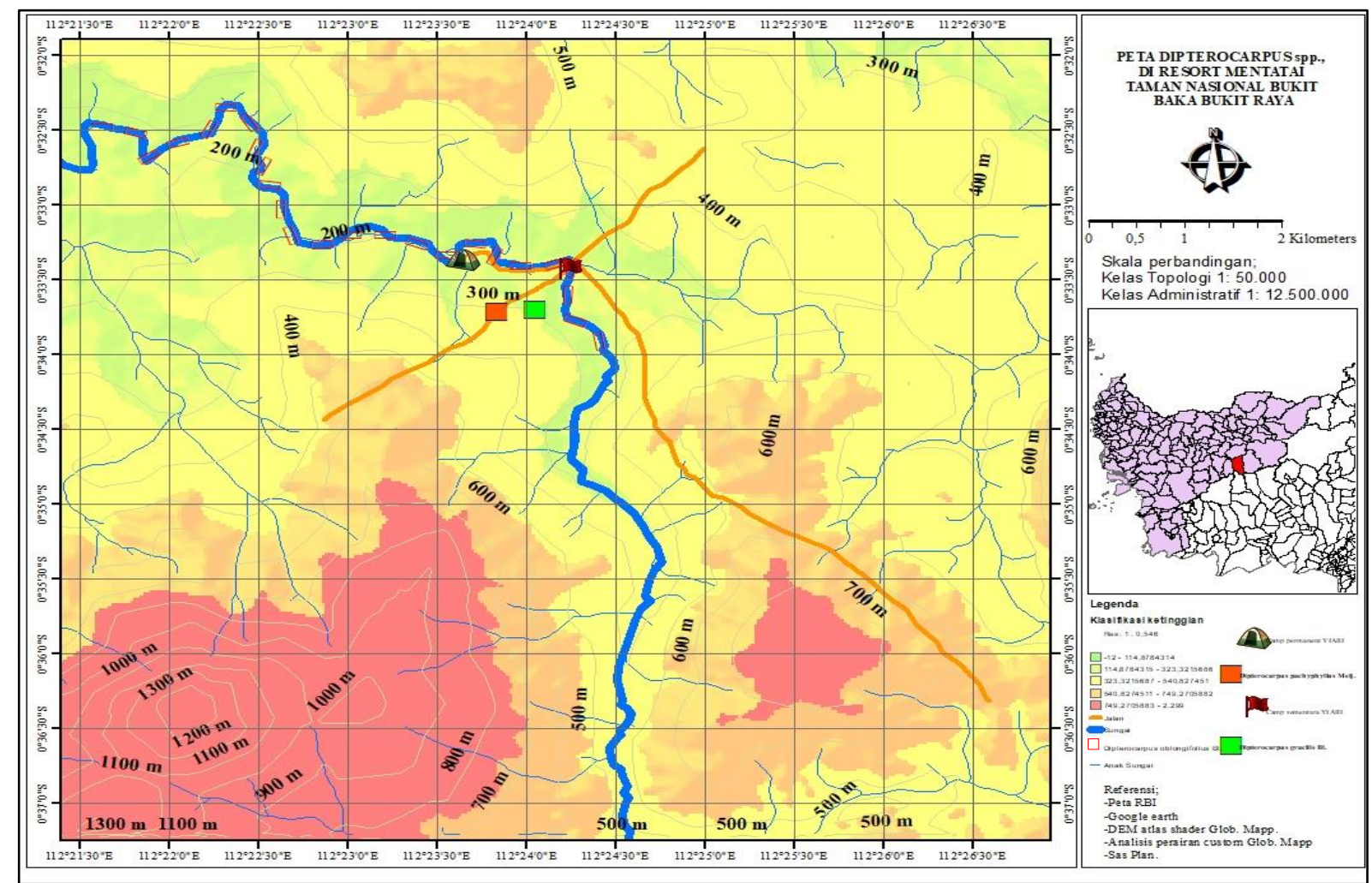

Gambar 1. Peta Dipterocarpus di Resort Mentatai Taman Nasional Bukit Baka Bukit Raya

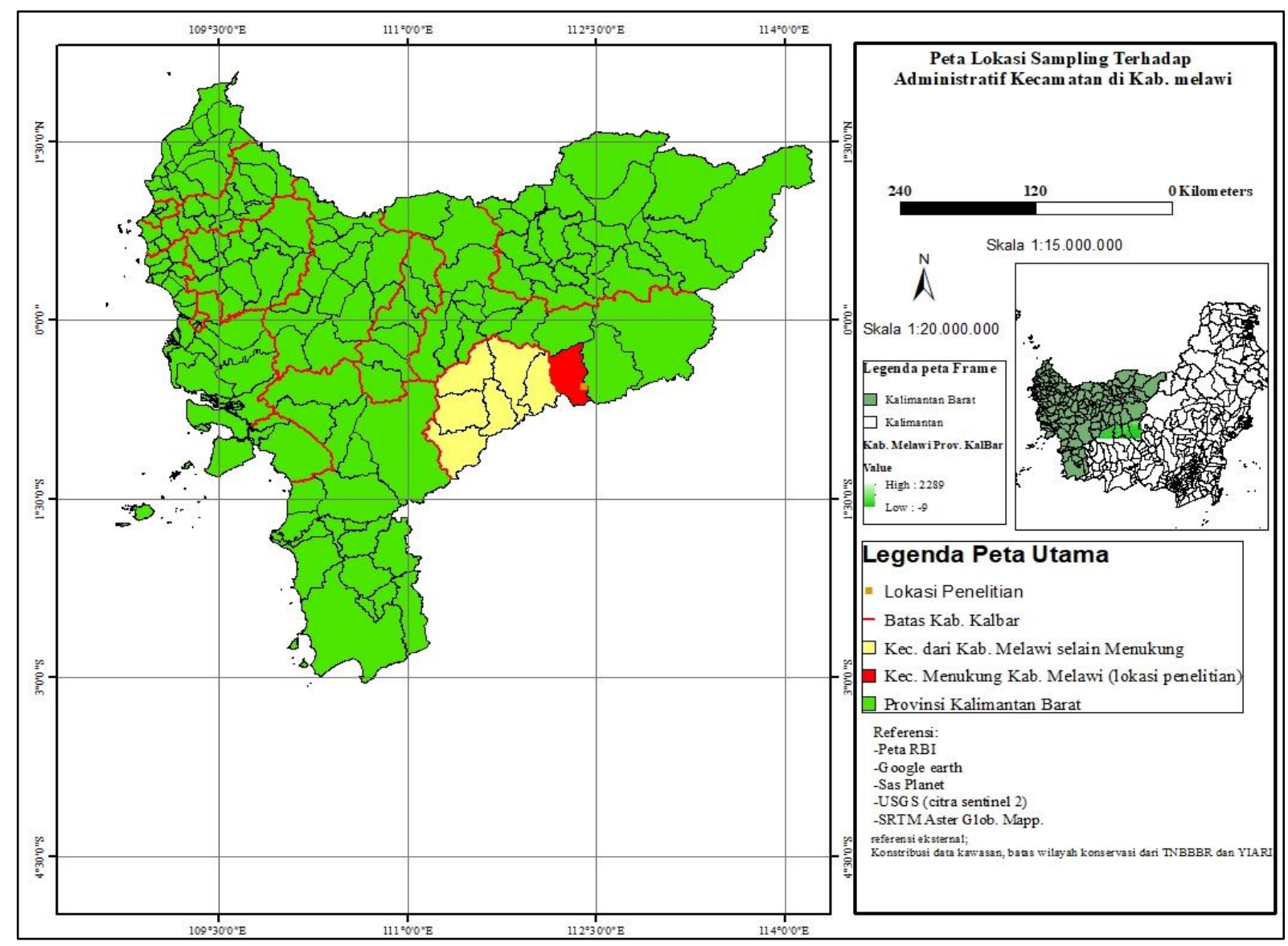

Gambar 2. Peta lokasi sampling terhadap administrasi Kecamayan di Kab. Melawi 


\subsection{Penyajian Data}

Data yang diperoleh akan dianalisa secara deskriptif, yaitu dengan mendeskripsikan ciri morfologi dari setiap sampel Dipterocarpaceae yang ditemukan.

\section{Hasil}

Hasil penelitian yang dilakukan di Resort Mentatai diperoleh Dipterocarpus yang terdiri dari 3 spesies yaitu, Dipterocarpus oblongifolius B1., Dipterocarpus gracilis B1., dan Dipterocarpus pachyphyllus Meijer. Jenis Dipterocarpus yang ditemukan dideskripsikan dengan mengamati karakter morfologi, diidentifikasi dan diklasifikasikan sebagai berikut;

Tabel 1. Karakter Dipterocarpus spp., yang terdapat di resort Mentatai

\begin{tabular}{lllllr}
\hline No. & Jenis & $\begin{array}{l}\text { Karakter hidup } \\
\text { (berkoloni/soliter) }\end{array}$ & $\begin{array}{l}\text { Morfologi batang, calyx } \\
\text { permukaan calyx buah. }\end{array}$ & buah, \\
\hline 1 & D. oblongifolius B1. & Berkoloni & $\begin{array}{l}\text { Membengkok, globosi tanpa rusuk, } \\
\text { glabrous }\end{array}$ \\
2 & D. gracilis Bl. & soliter & $\begin{array}{l}\text { Lurus, alati dengan rusuk, tomentose } \\
\text { Lurus, tidak diketahui }\end{array}$ & \\
3 & D. pachyphyllus Meij. & soliter & &
\end{tabular}

\section{Taksonomi, Deskripsi dan Habitat Dipterocarpus spp., di Resort Mentatai}

Identifikasi dan deskripsi jenis Dipterocarpus spp., yang ditemukan di Resort Mentatai dilakukan perbandingan dengan kemiripan morfologi dari referensi perkembangan taksonomi Dipterocarpus Gaertn. (1788). Kombinasi karakter dimaksudkan untuk menggambarkan karakter Dipterocarpus spp., di Resort Mentatai. Setiap bagian tersebut tersusun dalam bilibiografi dan sitasi taxonomy singkat Dipterocarpus Gaertn. (1788) terhadap jenis yang terdapat di Resort Mentatai dan deskripsi Dipterocarpus spp., yang terdapat di Resort Mentatai, sebagai berikut;

Bilibiografi dan sitasi taxonomy singkat Dipterocarpus Gaertn. (1788) terhadap jenis yang terdapat di Resort Mentatai

Dipterocarpus Gaertn. f., Fruct. Sem. Pl. 3 (1788) 51; Bl. Bijdr. (1825) 223; Dyer, Fl. Brith. India 1 (1875) 295; Vesque, Compt. Rend. Ac. Sc. 78 (1874) 625; A. DC., Prodr. 16 (2) (1868) 606; Burck in Treub, Ann. Jard. Bot. Buitenz. 6 (1887) 185; Heim, Recherch. Dipt. (1892) 514; Brandis, J. Linn. Soc. Botany 31 (1895) 24; Brandis et Gilg, Dipt. in Engler, Naturl. Pflanzenfam. 3 (6) (1895) 255; Foxw. Phillip. J. Science 67 (1938) 243; Sym. Note Mal. Dipt. III (1935) 321, Smitinand, Nat. Hist. Bull. Siam Soc. 19 (1958) 68 ; Ashton, Gard. Bull. Singapore 20 (1963) 157; Gard. Bull. Sing. 31 (1978); in Steen. Fl. Mal. 9 (2) (1982) 291. P1. 1.

Nama yang berbeda dan publikasi tentang sinonima Dipterocarpus Gaertn. $f$. (1788).

Pterigium costatum Correa, Oleoxylon balsaminifera Roxb., Mocanera verciniflua Blanco, Duvaliella problematica Heim, merupakan sinonima dari Dipterocarpus Gaertn., 
dinyatakan Ashton, Gard. Bull. Sing. 20 (1963) 233; in Steenis, Fl. Mal. 9 (2) (1982) 291, sebagai monograf Dipterocarpus. Precursors Dipterocarpus disampaikan Ashton, Gard. Bull. Sing. 20 (1963) 233. Berikut adalah daftar nama yang telah terselesaikan oleh Ashton;

- Pterigium Correa; Ashton, Gard. Bull. Sing. 20 (1963) 233; in Steenis, Fl. Mal. 9 (2) (1982) 291. Pterigium Correa (1806), dideskripsikan untuk jenis Pterigium costatum Correa, 2 sayap panjang dan 3 sayap pendek dengan bagian dasar fusi membentuk tabung mengindikasikan kemiripan terhadap konsep dan deskripsi Dipterocarpus Gaertn. (1788) yang lebih dahulu dideskripsikan. Kemiripan P. costatum Correa sebagai sinonim Dipterocarpus Gaertn., dipertegas oleh Ashton (1982) berlaku pro parte quad P. costatum (Gaertn. f) Correa (setengah bagian dari Pterigium costatum). Pterigium Correa diilustrasikan dalam Ann. Mus. Hist. Nat. Paris 8 (1806) 486, pl. 64.

- Mocanera Blanco; Ashton, Gard. Bull. Sing 20 (1963) 233; in Steenis, Fl. Mal. 9 (2) (1982) 291. Dimaksudkan untuk jenis Mocanera verciniflua Blanco, Fl. Filip. (1837) 446.

- Oleoxylon Roxb.; Ashton, Fl. Mal. 9 (2) (1982) 291. Oleoxylon balsaminifera Roxb., dideskripsikan sebagai pohon besar penghasil minyak kering atau balsam yang tipis dan digunakan untuk mengecat. Indikasi damar (Pl. 4D) ditujukan untuk minyak yang mengering, balsam tipis mengindikasikan resin yang digunakan untuk proses pengecatan. Deskripsi pertama Oleoxylon balsaminifera Roxb., terdapat dalam Trans. Soc. Arts London (1805) 412. Kesamaan Oleoxylon balsaminifera Roxb., mengarah pada Dipterocarpus alatus Roxb. ex Don, Gen. Hist.,1 (1831) 813, keduanya merupakan native Chittagong. selain itu, 2 jenis (D. costatus Buch.-Ham., dan D. incanus Roxb.) native Chittagong yang terdapat dalam Roxb. Hort. Beng. p. 42 dan p. 93, hanya diketahui nama tanpa deskripsi jelas (Roxb. Hort. Beng. p. 42, p. 93; Don, 1831) dan dianggap sebagai sinonima dari D. alatus Roxb. ex Don.

- Duvaliella Heim; Ashton, Gard. Bull. Sing. 20 (1963) 233; in Steenis, Fl. Mal. 9 (2) (1982) 291. Duvaliella merupakan genus untuk jenis tunggal Duvaliella problematica Heim, 1011. Ephiteton jenis ini merujuk pada karakter yang dianggap sebagai penyimpangan oleh Heim untuk ditempatkan ke dalam genus dari Dipterocarpaceae. Nama ini dimaksudkan sebagai penghormatan terhadap konstribusi Duval-Jouve oleh Heim. Setidaknya untuk Duvaliella problematica Heim, merupakan kasus dimana Doona Thw., belum direduksi sebagai seksi Shorea Roxb., sehingga setiap nama yang disinggung masih aktif digunakan di zamannya. Heim mendeskripsikan Duvaliella memiliki pericarp gundul dan tipis seperti Hopea Roxb., dan memiliki persamaan yang paling dekat dengan Doona.

- Heimiatoma Pierre; Ashton, Gard. Bull. Sing. 20 (1963) 233; in Steenis, Fl. Mal. 9 (2) (1982) 291. Heimiatoma Pierre merupakan genus tunggal yang dikelompokan ke 
dalam tribus yang sama dengan Dipterocarpus Gaertn., oleh Pierre sebagai Heimiatomees Pierre, Fl. Forest. Cochinch. 3 (1892) 2 halaman setelah penjelasan pl. 259. Dipterocarpaceae pada sistem Pierre dibagi menjadi 5 tribus; trib. 1 Heimiatomees ( genus; Dipterocarpus Gaertn. f. et Heimiatoma Pierre; sinonima yang diragukan dengan Dipterocarpus (?) codorensis Pierre, Fl. Forest. Cochinch. 3 (1892) pl. 214 dan deskripsi halaman kedua setelah penjelesan pl. 259), trib. 2 Shorees (genus; Shorea, Parashorea, Anthoshorea, Pentacme, Doona et Anisoptera), trib 3 Vateriees (genus; Vateria, Retinodendron, Pachynocarpus, Vatica, Synaptea, Cotylelobium, Stenomonoporus et Monoporandra), trib. 4 Hopees (Hopea, Hancea et Balanocarpus), trib. 5 Dryobalanopsees (genus; Dryobalanops). Genera Dipterocapaceae pada sistem ini berjumlah 20 dan telah direduksi pada sistem yang lebih update. Contohnya; Hancea, Balanocarpus merupakan bagian dari Hopea, kemudian seluruh tribus Shorees terkecuali Parashorea dan Anisoptera dikelompokan sebagai infragenerik taksa dari Shorea Roxburhg oleh Ashton.

Deskripsi Dipterocarpus spp., yang terdapat di Resort Mentatai

Pohon berukuran sedang hingga besar, banir, pipih, cekung (Pl. 3). Pepagan bersisik, abu-abu hingga coklat, pepagan dalam kuning, sering pucat, kayu kuning (Pl.2B, 4A, 5BC). Ranting menjuntai atau tidak, bagian terminal sering tomentose atau glabrous. Gemmae terminalis pada ranting berukuran besar, sering dengan indumentum atau glabrous, stipule fusi menutupi terminal bud, persistent atau gugur. Stipule sering caducous.

Daun alternate, lamina coriaceous, elliptico, oblong, elliptico-oblong, lanceolate, acute apex, margin sinuate, petiole geniculate, dengan indumentum atau glabrous. Tulang midbrid tenggelam di permukaan adaxial dan muncul di abaxial lamina, tulang sekunder lurus dan hanya melengkung di dekat margin, tulang intercostal jelas scalariform.

Bunga majemuk raceme, pedunculous pendek, tersusun zig-zag, dengan tomentose atau glabrous. Bunga besar, gemmae floriferae spidle, sering tomentose. Receptacle tomentose atau glabrous. Calyx 5 valvate, basal fusi, 2 calyx sering lebih panjang dibandingkan 3 calyx lainnya. 2 calyx panjang oblanceolate, sphatulate, rounded apex, sering tomentose atau glabrous. Petal 5 imbricate, putih, sering dengan garis merah muda dari bagian dasar hingga sepanjang median axis menuju apex.

Buah dengan 5 calyx, menyatu di bagian dasar membentuk tabung, tabung calyx dengan indumentum; tomentose, setose atau glabrous, 2 calyx oblanceolate, sphatulate, sering rounded apex, 3 calyx lainnya berukuran lebih pendek.

Kunci identifikasi Dipterocarpus spp., yang terdapat di Resort Mentatai Taman

Nasional Bukit Baka Bukit Raya. 
1a. Habitus pohon dengan batang yang membengkok ke arah sungai, terminal bud panjang dengan stipule fusi merah muda, buah dengan 5 sirip, alati, tomentose cream, calyx tube oblong dengan basi yang menyempit Dipterocarpus oblongifolius Blume

b. Habitus pohon dengan batang yang tidak demikian (sering lurus), terminal bud cendrung pendek, tabung calyx glabrous, dengan basi rounded ..........................2

2a. Tulang sekunder abaxial lamina tomentose cream, berjumlah 12-20 pasang, basis lamina acute, calyx buah globosi............................Dipterocarpus gracilis Blume

b. Tulang sekunder abaxial lamina glabrous, berjumlah 11-13 pasang, basi lamina rounded, ovate. ..Dipterocarpus pachyphyllus Meijer

Dipterocarpus oblongifolius Bl. Mus. Bot. Lugd. Batavorum 2 (1852) 36. -P1. 2 et P1. 3.

Pohon besar, diameter $150 \mathrm{~cm}$, tinggi $32.5 \mathrm{~m}$, banir pipih, batang umumnya bengkok ke arah sungai, terete, pepagan bersisik (Pl. 2B), pepagan luar abu-abu, pepagan dalam kuning pucat, kayu kuning, aroma resin takikan tidak terlalu aromatis. Percabangan awal dichotomous, akhirnya simpodial, ranting menjuntai, pada beberapa individu hampir menyentuh permukaan air di sungai (Pl. 3), ranting pipih, stipule amplexicaul, fugaceous, lanceolate, rounded apex, bagian dalam dengan rambut kelenjar, merah muda, membalut gemmae terminalis, caducous, meninggalkan bekas berbentuk cincin.

Daun elliptico, oblong, lanceolate, $16-25 \times 6-9 \mathrm{~cm}$, acuminate apex, petiole $0.75-2 \mathrm{~cm}$, margin sinuate, acute basis, adaxial lamina laevis, abaxial laevis, pertulangan pinnate, midbrid dan costa adaxial tenggelam, glabrous, pada abaxial muncul, dengan indumentum putih. Tulang sekunder 13-15 pasang, lurus dari midbrid menuju margin foli, sudut $45^{\circ}-50^{\circ}$, tulang intercostal scalariform (P1. 2E).

Bunga majemuk raceme, supra axillaris (P1. 1A), calyx valvate, basal fusi, 2 calyx lebih panjang, 0.2-0.3 x 1-1.4 cm, oblanceolate, coriaceous, terdapat trichome, abu-abu kecolatan di bagian luar dan dalam, rounded apex, 3 calyx pendek acute apex, 0.15-0.4 $\mathrm{x}$ 0.1-0.25 cm. Petal 5, imbricate, contortate apex, lanceolate, $5-6 \times 0.8 \mathrm{~cm}$, rounded apex, basis rounded, putih dengan merah muda di bagian dasar (Pl. 2C), stamen 9-13, syngenesious, gugur bersama petal, filament glabrous, lebih pendek dari anther, kering berwarna coklat kemerahan, mengkilap ketika terkena cahaya, panjang $0.4 \mathrm{~cm}$, anther $0.7 \mathrm{~cm}$, kuning, theca parallel, anther basifixed, oblong, ovarium inferior, conical, stylopodic, stylopodium menyempit dengan rambut cream, style $1.3-1.5 \mathrm{~cm}$, filiform, diameter 0.15 $\mathrm{cm}$, stigma clavate.

Fructus calyx 2 lebih panjang dibandingkan 3 lainnya (P1. 2D), oblanceolate, sphatulate, 8-13.5 x 1.3-1.8 cm, merah muda, rounded apex, dengan rambut kelabu di bagian dalam dan luar. 3 Calyx pendek berbentuk tabung 0.5-0.9 x 0.2-0.4 cm, bagian luar dan dalam ditutupi oleh indumentum, acute apex, tabung calyx ditutupi indumentum, oblong, diameter $0.8-1 \mathrm{~cm}$, basi menyempit. 
Kegunaan dan kearifan lokal jenis di Resort Mentatai; Masyarakat Dayak Ransa dan Limbai (Kalimantan Barat) mengenal jenis ini sebagai kensurai pantai dan bagian buah dapat digunakan sebagai umpan untuk memancing jenis ikan semah. Kayu dari jenis ini jarang digunakan karena batangnya yang cendrung membengkok.

Ekologi jenis di Resort Mentatai; Dipterocarpus oblongifolius ditemukan di sepanjang tepian sungai sandstone Mentatai dan melimpah pada ketinggian 70-139 mdpl, kisaran suhu 28-29 $\mathrm{C}$, air dengan $\mathrm{pH}$ 6.2-6.8. Vegetasi sekitar meliputi Saraca declinata, Myrmeconauclea strigosa, Ficus deltatoidea, Psychotria viridiflora, Psychotria sp., Eugenia sp., Shorea macrophylla, Shorea seminis.

Dipterocarpus gracilis B1. Bijdr. (1825) 224. -P1. 4.

Pohon, diameter 101,2 cm, tinggi 27.3m, banir pipih cekung, tinggi banir mencapai $125 \mathrm{~cm}$, pepagan bersisik, pepagan luar coklat kemerahan, pepagan dalam coklat kekuningan, kayu coklat merah muda hingga merah tua. Percabangan kanopi dichotomous dan berakhir simpodial, aroma resin tidak menyengat, dammar tembus cahaya (Pl. 4D). Ranting coklat, terete, terminal bud dengan indumentum coklat.

Daun alternate, petiole $1.5-2.5 \mathrm{~cm}$, geniculate lemah, lamina elliptico, oblong, 7.4-13.5 $x 3.3-8 \mathrm{~cm}$, coriaceous, apex acute, basis acute, margin sinuate, lamina adaxial laevis, abaxial scabrid dengan indumentum pendek coklat pada pertulangan. Pertulangan pinnate, midbrid tenggelam pada permukaan adaxial lamina, terdapat indumentum coklat, pada permukaan abaxial mucul, rounded, dengan indumentum coklat, tulang sekunder 14-20 pasang, sudut tulang sekunder $40^{\circ}-50^{\circ}$, pada bagian basal $70^{\circ}-80^{\circ}$, lurus dari midbrid ke margin foli, masing-masing tulang sekunder fusi dengan tulang sekunder berikutnya di margin, intercostal scalariform (Pl. 1B et $\mathrm{Pl} 4 \mathrm{~B})$.

Calyx fructus 2 panjang dan 3 pendek, calyx panjang lanceolate, oblanceolate, 1015.5 × 2-2.7 cm, coriaceous, merah muda, rounded apex, terdapat 1 tulang utama di tengah pada sayap, pertulangan antara reticulate (Pl. 4E-G), permukaan luar dan dalam terdapat stellate trichome yang longgar $(\mathrm{Pl} .4 \mathrm{~F})$, memadat pada bagian dasar calyx. Calyx pendek, 0.5-1.3 x 0.3-0.7 cm, berlipat, coriaceous. Tabung calyx ellipsoidal vertical, diameter $1-1.4 \mathrm{~cm}$, pedicelous $0.2-0.3 \mathrm{~cm}$ (Pl. 4C).

Ekologi Jenis di Resort Mentatai; jenis ini ditemukan pada ketinggian 250 mdpl, tanah liat kuning berpasir, humic soil, hutan campuran Dipterocarpaceae di Resort Mentatai TNBBBR.

Dipterocarpus pachyphyllus Meijer, Act. Bot. Neerlandica 12 (1963) 351.

Pohon besar, diameter 80-90 cm, banir pipih cekung, tinggi mencapai $2.5 \mathrm{~m}$, batang lurus. pepagan bersisik, pepagan luar coklat, papagan dalam coklat hingga merah muda, kayu orange kemerahan (Pl. B-C). Kanopi hemispherical dengan dahan dichotom kemudian berakhir simpodial. 
Daun alternate, petiole 2-2.5 cm, geniculate, ketika kering berwarna tengguli atau coklat gelap, permukaan glabrous. Lamina ovate, elliptico-oblong, oblong 8.5-12 x 5-6 cm, coriaceous, apex acute, acuminate, acumen mencapai $1.5 \mathrm{~cm}$, margin sinuate, beberapa lamina sukar terlihat sehingga seperti integer, basis rounded, cordate, asymmetrical, permukaan atas laevis, permukaan bawah laevis. Tulang midbrid tenggelam di adaxial lamina, permukaan; glabrous, muncul di abaxial lamina, permukaan;-. Tulang sekunder pinnate, 11-13 pasang, lurus dari midbrid menuju margin foli atau sedikit melengkung di seluruh bagian pada daun asymmetric, permukaan;-. Tulang intercostal jelas scalariform atau sukar terlihat, permukaan. Bunga dan buah tidak diketahui.

Ekologi Jenis di Resort Mentatai; jenis ini ditemukan pada tanah liat kuning, pada lereng perbukitan ketinggian $397 \mathrm{mdpl}$, hutan campuran Dipterocarpaceae di Resort Mentatai. Beberapa vegetasi yang ditemukan di sekitar yaitu, Homalomena sp., Gluta sp., Entada sp., Pinanga sp., Oncosperma sp., Popowia velutina dan Dryobalanops aromatica.

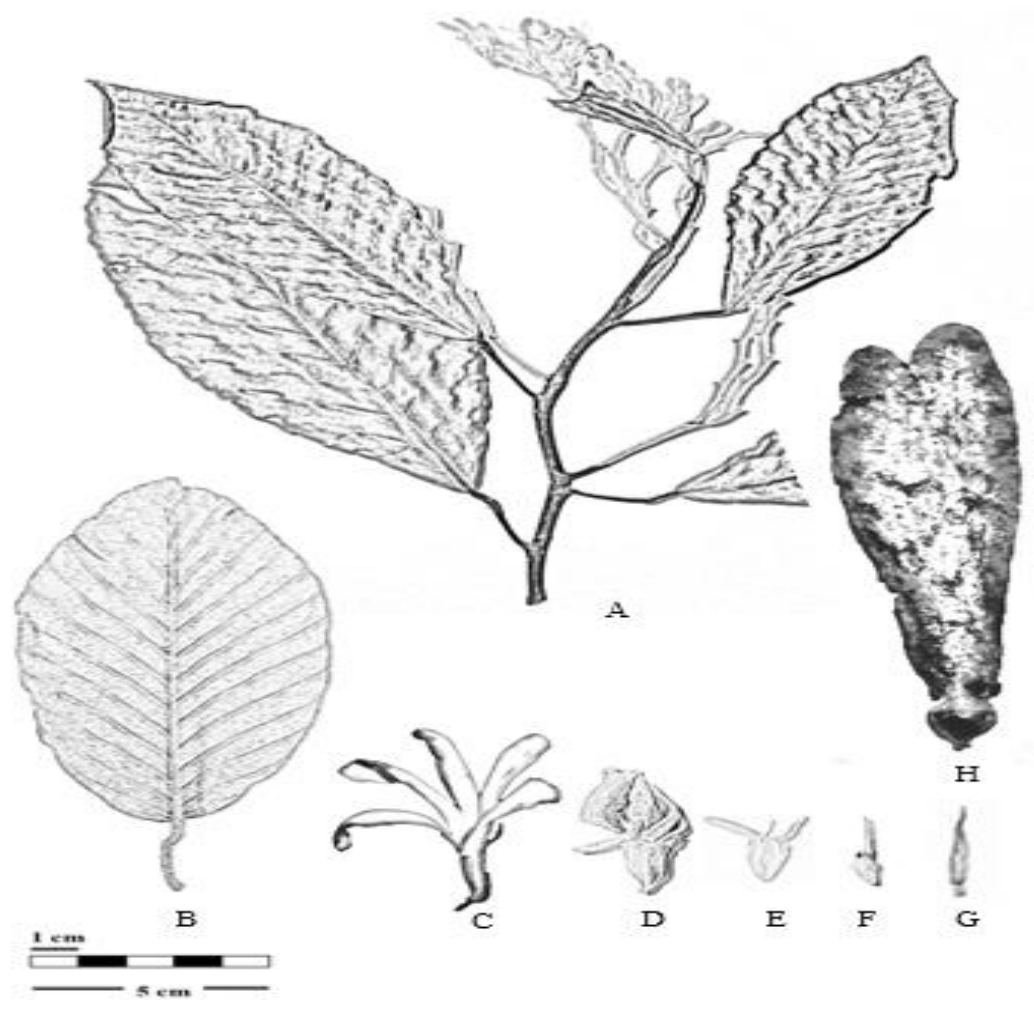

Plate 1. Dipterocarpus Gaertn.; A. Ranting, daun dan bunga majemuk receme (tak terbatas) D. oblongifolius Bl., B. Daun D. gracilis Bl., tampak abaxial C-G. Bunga D. oblongifolius Bl.; C-D. Bunga dengan petal contortate E. Receptacle dengan 5 calyx, 2 calyx lebih panjang F. Pistilum G. Stamen H. Buah pada D. gracilis $\mathrm{Bl}$ 

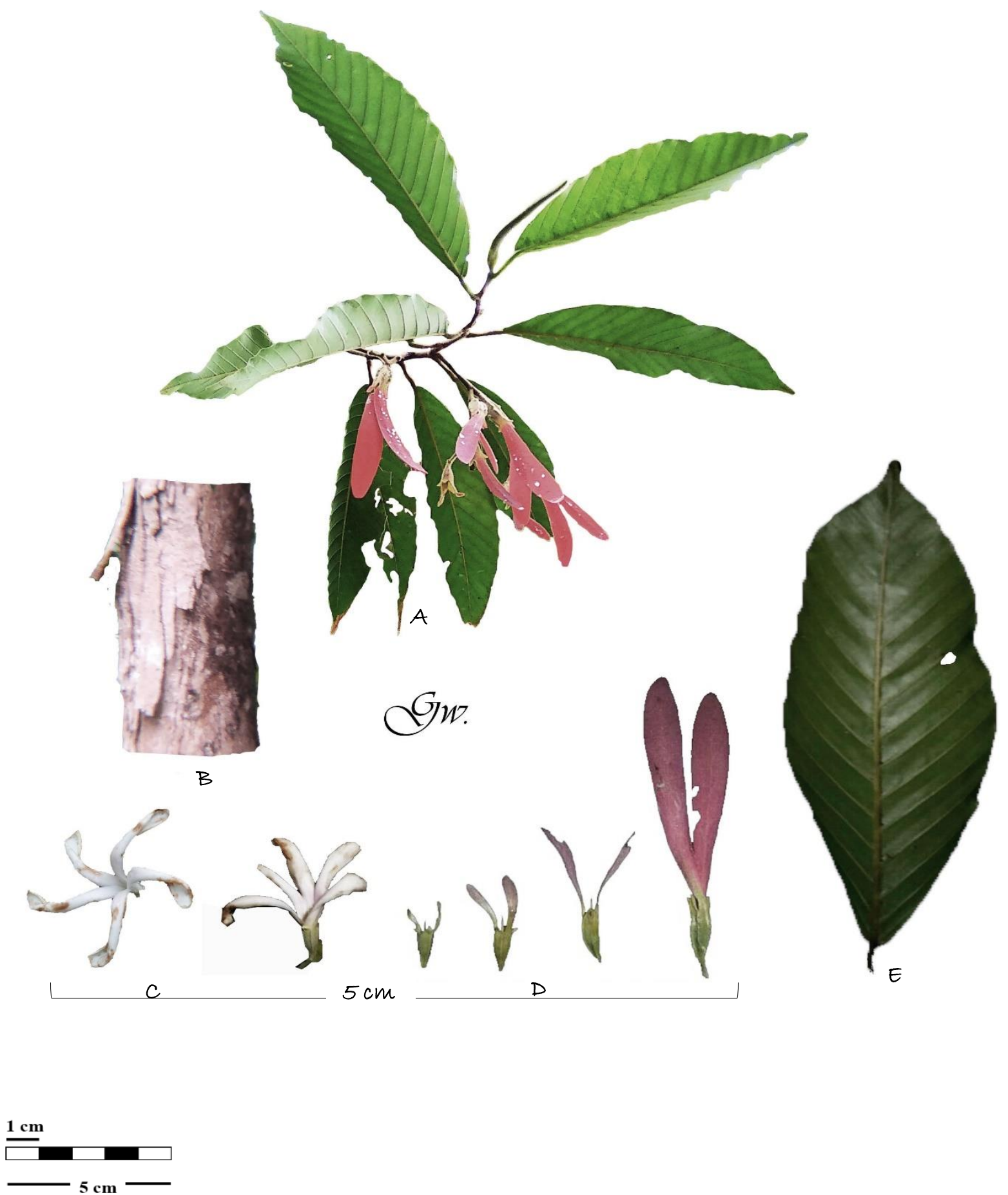

Plate 2. Dipterocarpus oblongifolius Blume; A. Ranting dan daun B. Batang memperlihatkan pepagan luar; tipe bersisik C. Bunga; petal contortate ketika jatuh berotasi D. Buah; memperlihatkan diferensiasi 2 calyx menjadi sayap 2 sayap E. abaxial daun; tulang sekunder lurus dan tulang intercostal scalariform. 


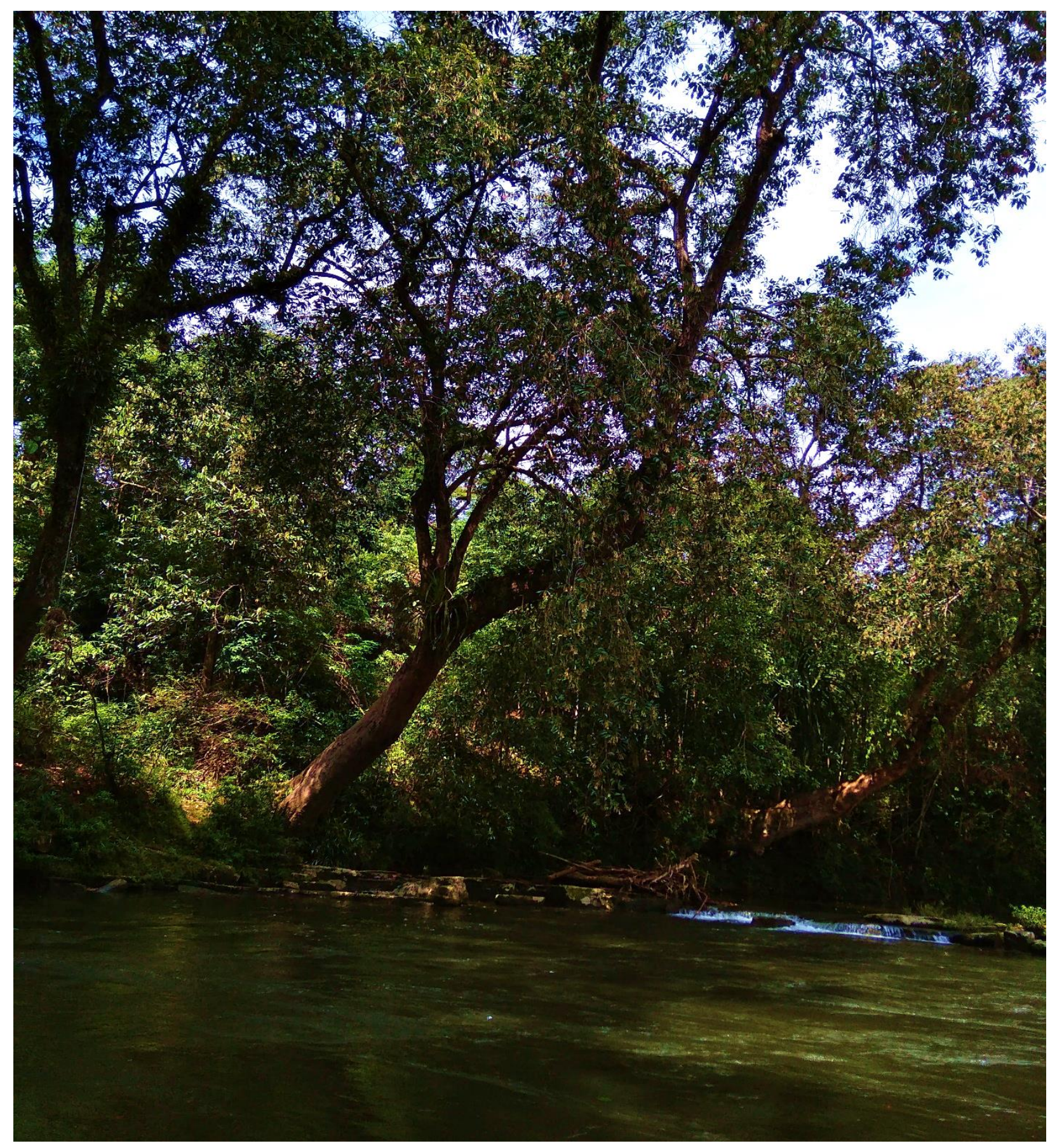

Plate 3. Dipterocarpus oblongifolius Bl.; Memperlihatkan Habitus dan 3 individu dewasa pada musim pembungaan Desember 2019, di Resort Mentatai (Foto oleh; G. Wibisono). 

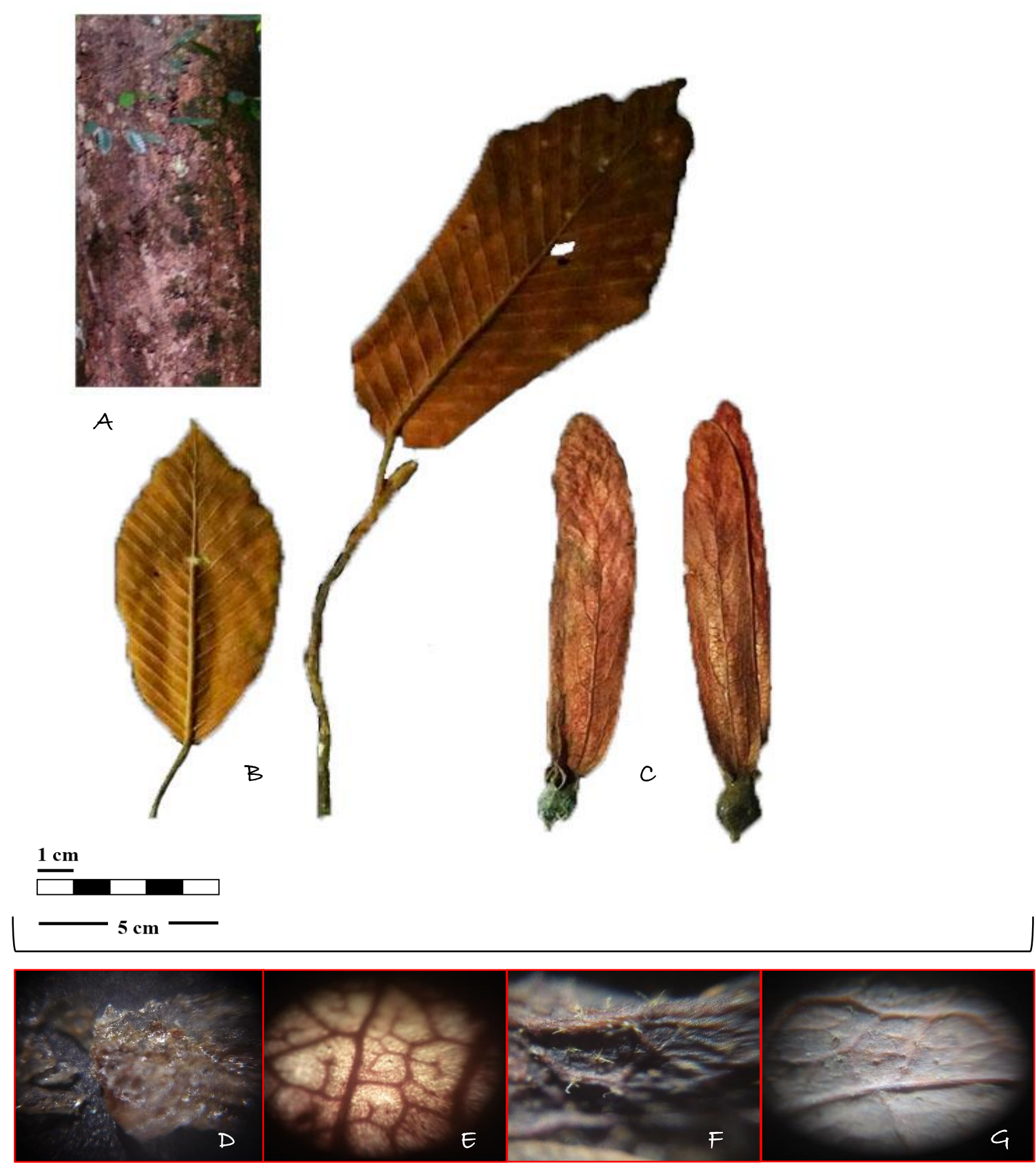

Plate 4. Dipterocarpus gracilis Bl., A. Batang memperlihatkan pepagan luar B. Ranting dan daun C. Buah. D. Damar (perbesaran 20x) E. Tulang tersier sayap buah reticulate (perbesaran 10x) F. Stellate trichome pada pertulangan primer dan sekunder fructus calyx (perbesaran 20x) G. Permukaan dalam fructus calyx (perbesaran 10x). 

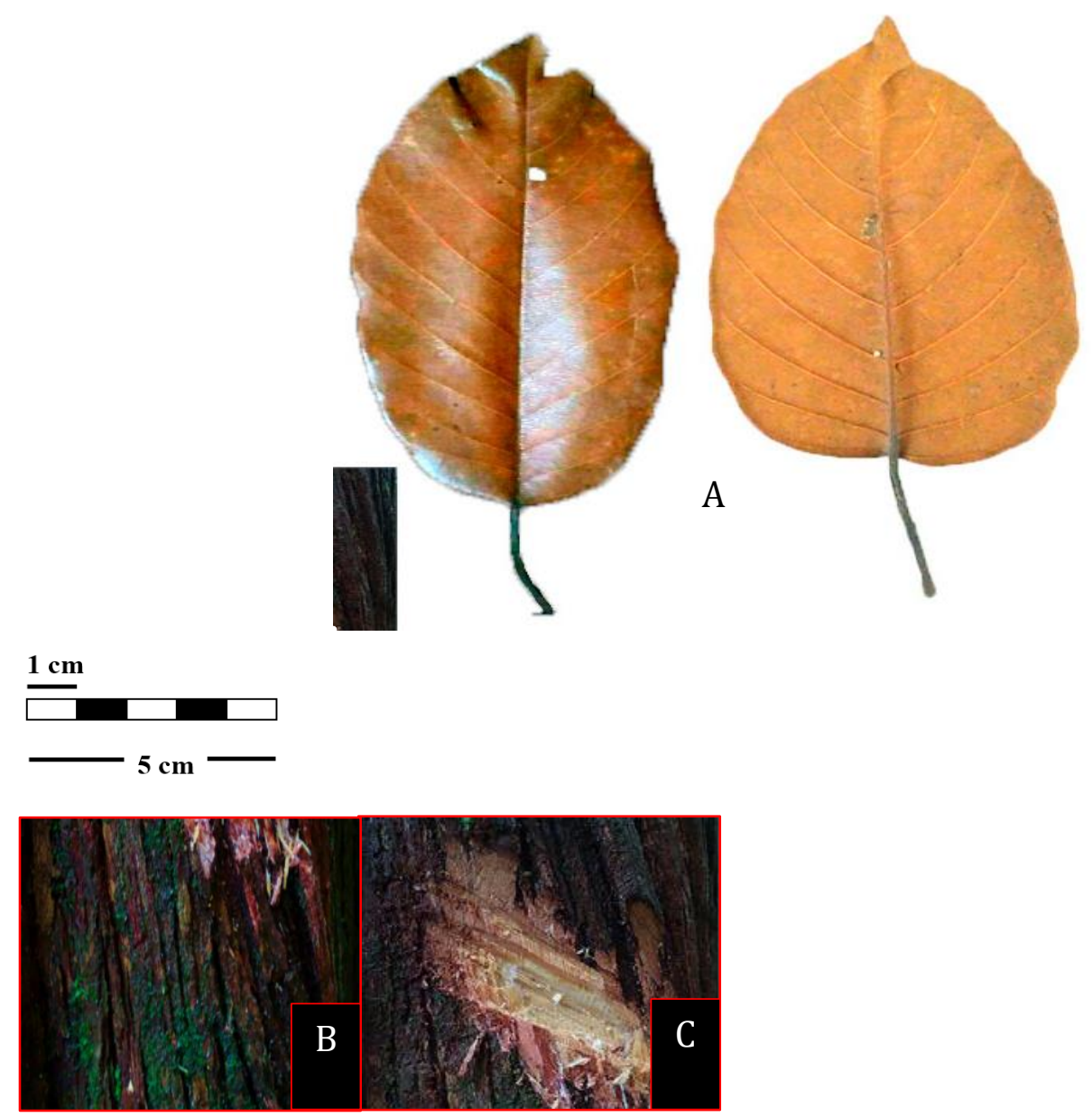

Plate 5. Dipterocarpus pachyphyllus Meijer, A. Habitus B. Takikan batang C. Daun.

\section{Pembahasan}

Dipterocarpus memiliki susunan calyx buah yang berbeda dengan Dryobalanops, Hopea dan Shorea yaitu, calyx buah berjumlah 5 tersusun valvate, 2 lebih panjang dan 3 pendek, menyatu di dasar dan membentuk calyx tube (tabung kelopak). Dipterocarpus gracilis dan Dipterocarpus oblongifolis yang ditemukan di Resort Mentatai memiliki kemiripan terhadap deskripsi seri Dipterocarpeae Brandis \& Gilg (1895), yang memiliki susunan calyx berbentuk seperti piala, tetapi berbeda untuk stamen berjumlah 20 atau lebih. Dipterocarpus oblongifolius memiliki jumlah stamen 15 (Ashton, 1982).

Pepagan batang Dipterocarpus yang terdapat di Resort Mentatai memiliki tipe pepagan bersisik sejalan dengan Newman et al. (1999). Petal jatuh terpisah dari receptacle, calyx dan pistilum. Setiap petal akan jatuh berotasi bersama stamen ketika musim pembungaan dan memiliki sifat aromatis yang mencolok. Karakter ini ditemukan pada $D$. oblongifolius sepanjang aliran sungai sandstone hutan campuran Dipterocarpaceae di Resort Mentatai. Xiwen et al. (2007) menyatakan, Dipterocarpus 
memiliki minyak aromatis resin putih. Karakter pertulangan pada 2 sayap panjang buah D. oblongifolius dan $D$. gracilis tersusun reticulate, memiliki kemiripan dengan deskripsi pertama Dipterocarpus Gaertner (1788) yang memperlihatkan illustrasi buah Dipterocarpus costatus dan Dipterocarpus turbinatus.

Karakter organ vegetatif daun Dipterocarpus di Resort Mentatai, memiliki perbedaan morfologi pada margin foli sinuate, pertulangan sekunder lurus dan tulang intercostal scalariform. Individu juvenile pada populasi D. oblongifolius dan D. gracilis memiliki tepian daun yang sering integer. Permudaan Dipterocarpus menurut Ashton (1982), dapat dibedakan dengan genus lainnya pada gemmae terminalis atau terminal bud pada rachis yang sering berukuran besar dan sering dengan stipule berpasangan yang mengalami fusi menutupi gemmae terminalis.

Buah Dipterocarpus oblongifolius memiliki perbedaan dengan Dipterocarpus gracilis. Sayap pada Dipterocarpus oblongifolius memiliki struktur alate yaitu epicarp dan 2 calyx panjang yang lebih tipis. Karakter intervenium calyx alate pada buah $D$. oblongfolius terdapat dalam Burck in Treub (1887), yaitu D. oblongifolius diklasifikasikan ke dalam seksi Alati. D. oblongifolius terdapat di sepanjang sungai sandstone Resort Mentatai dan berlimpah pada kisaran ketingian 70-140 mdpl. Blume (1852), mendeskripsikan lokasi sebaran D. oblongifolius terdapat di Borneo. Resort Mentatai yang terletak di Kalimantan Barat merupakan Provinsi yang sesuai terhadap keberadaan jenis tersebut. Habitat Sungai sandstone Resort Mentatai merupakan jalur endapan material dan mineral batuan. Nama vernacular masyarakat Ransa dan Limbai mengenal jenis ini sebagai kensurai pantai (pantai memiliki arti lokal masyarakat sebagai pasir coklat sungai sandstone Mentatai). Karakter habitat dan terminologi nama vernacular sesuai dengan deskripsi dan catatan Ashton in Steenis (1983) yang menyatakan, D. oblongifolius hidup berkoloni di tepian sungai berarus deras dan secara lokal dikenal sebagai ensurai atau gensurai di daerah Kalimantan Utara. Vegetasi yang sering ditemukan hidup berasosiasi dengan D. oblongifolius adalah Benstonia epifitica.

Blume (1825), mendeskripsikan lokasi Dipterocarpus gracillis ditemukan di "sylvis montiam Parang Provinciae Tjanjor dan Provinciae Bantam'. Nguyen et al. (2015), memperlihatkan peta tentang proses perubahan nama Provinsi Pulau Jawa. Tjanjor (Cianjur) merupakan bagian dari Jawa Barat, sedangkan Wilayah Bantam merupakan Banten. Sumardi (2020) mendeskripsikan, Gunung Parang merupakan nama yang mulai digunakan tahun 1815 dan berganti nama sebagai wilayah administratif Sukabumi. Gunung Parang yang tercatat sebagai lokasi D. gracilis Blume (1825), merupakan bagian dari afdeling Provinsi Tjanjor (Cianjur) (Sumardi, 2020).

Dipterocarpus gracilis tercatat ditemukan di Kalimantan yaitu di Sampit dan Lembah Rejang (Ashton, 1982 dalam Steenis, 1983). Newman et al. (1999), menyatakan bahwa D. gracilis ditemukan di Pulau Kalimantan, kecuali bagian Barat. Catatan 
keberadaan jenis di Resort Mentatai Kalimantan Barat sejalan dengan Ashton (1892) dalam Steenis (1983) yang menyatakan, D. gracilis merupakan satu dari beberapa anggota Dipterocarpaceae dengan wilayah distribusi yang luas. Masyarakat lokal yang tinggal di sekitar Resort Mentatai menjelaskan bahwa dari Resort Mentatai ke Kalimantan Tengah dapat ditempuh dengan berjalan kaki sekitar 1-2 hari memotong bukit. Dipterocarpus gracilis ditemukan di tanah liat kuning berpasir, ketinggian 250 mdpl, hutan campuran Dipterocarpaceae Resort Mentatai Kalimantan Barat. Deskripsi habitat D. gracilis Resort Mentatai memiliki ketinggian yang sesuai dengan (Ashton, 1982 dalam Steenis, 1983; Ashton dalam Soepadmo et al., 2004; Newman et al., 1999) yaitu, di bawah ketinggian 800 mdpl.

Karakter D. gracillis yang ditemukan di Resort Mentatai memiliki tabung calyx globose dengan epicarp tebal dan keras. Burck dalam Treub (1887), menempatkan Dipterocarpus gracilis Blume ke dalam seksi Globosi berdasarkan tabung calyx globose pada buah. Karakter susunan valvate dan tabung calyx menjadi dasar klasifikasi Ashton (1982) dalam Steenis (1983), menempatkan D. gracilis ke dalam Dipterocarpeae. Karakter piala berbentuk seperti kendi atau guci memiliki kemiripan dengan Dipterocarpeae Brandis et Gilg (1895). Perbedaan terdapat pada rentang ukuran petiole D. gracilis 1.5-2.5 cm yang ditemukan di Resort Mentatai terhadap deskripsi Ashton (1982) yaitu petole 2-2.5 cm. Rentang panjang petiole memiliki kemiripan dengan Newman et al. (1999) yaitu 1.6-2.5 cm yang memiliki perbedaan batas rentang terkecil $0.1 \mathrm{~cm}$ dengan spesimen dari Resort Mentatai.

Dipterocarpus pachyphyllus Meijer (1963), merupakan varietas dari D. lowii dengan daun yang lebih kecil (foliis minoribus) dan merupakan sinonima dari D. lowii var. microphylla Wood in Sched. Distribusi jenis dalam deskripsi Ashton (1982), untuk Malesia; Borneo Timur meliputi Sabah, Brunei dan Sarawak. Jenis ini ditemukan di Resort Mentatai, Melawi, Kalimantan Barat pada tipe habitat tanah liat berpasir tidak jauh dari S. inappendiculata Burck pada ketinggian 397 mdpl. Jumlah tulang sekunder lebih sedikit dari D. lowii. Terdapat beberapa perbadaan pada basis lamina untuk beberapa daun bertipe asimetris.

\section{Kesimpulan}

Berdasarkan hasil penelitian yang telah dilakukan dapat disimpulkan, bahwa Dipterocarpus yang ditemukan di Zona Rimba Resort Mentatai Seksi Pengelolaan Taman Nasional Wilayah I, Taman Nasional Bukit Baka Bukit Raya (TNBBBR) Kalimantan Barat terdiri dari 3 jenis yaitu; D. oblongifolius Bl., D. gracilis Bl., dan D. pachyphyllus Meij. Karakter hidup D. oblongifolius Bl., berkoloni sepanjang aliran sungai sandstone Mentatai dan berperawakan batang membengkok. Jenis D. gracilis Bl., dan D. pachyphyllus Meij., hidup soliter serta memiliki perawakan batang lurus serta pada tanah liat berpasir. Calyx Buah D. oblongifolius Bl., memiliki karakter alati, 
menyempit pada basis, terdapat rusuk dan permukaan tomentose, sedangkan $D$. gracilis Bl., memiliki tipe calyx buah globosi, rounded basis dan glabrous.

\section{Ucapan Terima Kasih}

Penulis mengucapkan terima kasih yang sebesar-besarnya kepada Community Development and Outreaching Universitas Tanjungpura, Jurusan Biologi Fakultas MIPA, Universitas Tanjungpura, Balai Taman Nasional Bukit Baka Bukit Raya dan Yayasan IAR Indonesia.

\section{Daftar Pustaka}

Angiosperm Phylogeny Group. 2016. An Update of the Angiosperm Phylogeny Group Classification for the Orders and Families of Flowering Plants: APG IV. Botanical Journal of Linnean Society 181: 1-20.

Ashton PS. 1983. Dipterocarpaceae. In: Steenis CGGJV. (ed.) Flora Malesiana, Spermatophyta, ser. 1, v.9 (2), Lembaga Ilmu Pengetahuan Indonesia, Bogor.

Ashton, PS, 1978, 'Flora Malesiana Precursores: Dipterocarpaceae', Gard. Bull. Sing., $31(1): 5$

Bawa KS. 1998. Conservation and Genetic Resources in the Dipterocarpaceae. In: Appanah \& Turnbul. (ed.) A Review of Dipterocarps Taxonomy, Ecology and Silviculture. Center for International Forestry research, Bogor. Pp. 45.

Brandis D, Gilg E. 1895. Dipterocarpaceae. In: Engler, A (ed). Die Nturlichen Pflanzenfamilien. Wilhelm Engelman, Leipzig.

Brandis D. 1895. An Enumeration of the Dipterocarpaceae Based Chiefly Upon the Specimens Preserved at the Royal Herbarium and Museum, Kew and the British Museum; With Remarks on the Genera and Species. J. Linn. Soc. Botany 31: 1-148.

Chua, LSL, Suhaida, M \& Aslina, B, 2012, Spesies Dipterokarpa Terancam di Semenanjung Malaysia, Institut Penyelidikan Perhutanan Malaysia, Kepong.

Effendy E. 2009. Rencana Pengelolaan Jangka Panjang Taman Nasional Bukit Baka Bukit Raya Periode 2010 S/D 2029. Balai Taman Nasional Bukit Baka Bukit Raya, Sintang.

Heywood VH, Brummit RK, Culham A, Seberg O. 1978. Flowering Plant Families of The World. The University of Reading, UK.

Newman MF, Burgess PF, Whitemore TC. 1999. Pedoman Identifikasi Pohon-pohon Dipterocarpaceae Pulau Kalimantan. Terjemahan: Ratna Rosiana Budiman. PROSEA Indonesia, Bogor.

Nguyen, N, Griffin, J, Cipta, A \& Cummins, R, 2015, Indonesian's Historical Earthquakes, Modelled Examples for Improving the National Hazard Map. Record 2015/23, Geoscience Australia, Camberra. 
Purwaningsih. 2004. Sebaran Ekologi Jenis-Jenis Dipterocarpaceae di Indonesia. Biodiversitas 5 (2): 89-95

Raharjo H. 2017. Rencana Pengelolaan Jangka Panjang Taman Nasional Bukit Baka Bukit Raya Kabupaten Sintang Dan Melawi Provinsi Kalimantan Barat Serta Kabupaten Katingan Provinsi Kalimantan Tengah Periode 2018 - 2027, Sintang. Rugayah, Widjaja EA, Praptiwi. 2005. Pedoman Pengumpulan Data Keanekaragaman Flora. Pusat Penelitian Biologi LIPI, Bogor.

Singh G. 2009. Plant Systematics, Third Edition. Science Publishers, New Delhi.

Sumardi E. 2020. Sukabumi Sebelumnya Bernama Gunung Parang. https:// portal.sukabumikota.go.id. [21 July 2020].

Symington CF. 1935. Notes on Malayan Dipterocarpaceae III. Gard. Bull. Sing. 10: 321.

Tjitrosoepomo G. 1991. Taksonomi Umum (Dasar-Dasar Taksonomi Tumbuhan). Gadjah Mada University Press, Yogyakarta.

Tucker AO, Calabrese L. 2005. The Use and Methods of Making a Herbarium/Plant Specimens an Herb Society of America Guide. The Herb Society of America 9019 Kirtland Chardon Rd, Kirtland.

Xiwen L, Jie L, Ashton PS. 2007. Dipterocarpaceae. Flora of China 13: 48-54. 